\title{
The importance of cancers prophylaxis among women
}

Znaczenie profilaktyki nowotworów wśród kobiet

\section{Małgorzata Pabiś1 $\oplus^{\oplus}$, Kinga Augustowska-Kruszyńska ${ }^{\oplus}$, Weronika Kozicka², Kamila Kułaczkowska², Diana Kuzioła²}

\author{
'Chair of Development in Nursing, Department of Basic Nursing and Medical Teaching, \\ Faculty of Health Sciences, Medical University of Lublin, Poland/ \\ Katedra Rozwoju Pielęgniarstwa, Zakład Podstaw Pielęgniarstwa i Dydaktyki Medycznej, \\ Wydział Nauk o Zdrowiu, Uniwersytet Medyczny w Lublinie \\ ${ }^{2}$ First Degree Nursing Student, Chair of Development in Nursing, Department of Basic Nursing and Medical Teaching, \\ Faculty of Health Sciences, Medical University of Lublin, Poland/ \\ Studentka Pielęgniarstwa I stopnia, Katedra Rozwoju Pielęgniarstwa, Zakład Podstaw Pielęgniarstwa i Dydaktyki Medycznej, \\ Wydział Nauk o Zdrowiu, Uniwersytet Medyczny w Lublinie \\ CORRESPONDING AUTHOR/AUTOR DO KORESPONDENCJI: \\ Małgorzata Pabiś \\ Zakład Podstaw Pielęgniarstwa i Dydaktyki Medycznej, Katedra Rozwoju Pielęgniarstwa \\ Uniwersytet Medyczny w Lublinie \\ ul. Staszica 4/6, 20-081 Lublin \\ e-mail: malgorzata.pabis@umlub.pl
}

\section{STRESZCZENIE ZNACZENIE PROFILAKTYKI NOWOTWORÓW WŚRÓd KOBIET}

Wprowadzenie. Późno wykryty rak piersi i szyjki macicy to dwa z najgroźniejszych nowotworów ze względu na ograniczone możliwości terapeutyczne oraz wysoki stopień umieralności kobiet. Prowadzone badania naukowe, programy profilaktyczne i kampanie społeczne nie przyczyniają się do zmian w postawach Polek, które nie zgłaszając się na badania wykluczają możliwość wcześniejszej diagnozy.

Cel pracy. Celem pracy jest analiza danych epidemiologicznych dotyczących występowania nowotworów u kobiet w Polsce oraz zwrócenie uwagi na znaczenie profilaktyki w tym zakresie.

Materiał i metody. Do analizy epidemiologicznej wykorzystano dane z Krajowego Rejestru Nowotworów, Głównego Urzędu Statystycznego oraz Naczelnej Izby Lekarskiej za lata 2014-2018 opracowane za pomocą metody opisowej.

Omówienie i dyskusja. Co roku zwiększa się liczba zgonów na nowotwory (NIK, 2018). Profilaktyka, pomimo finansowania z budżetu państwa, nie przyniosła zamierzonego celu. Ponad połowa badanych mężczyzn twierdziła, że kobiety po mastektomii tracą swoją atrakcyjność i nie zaczęliby nowego związku z nimi. Pomimo tego, że stali, wieloletni partnerzy akceptują wygląd swojej partnerki po mastektomii, to i tak kobiety wstydzą się swojej seksualności, co wiąże się z problemami w związku lub jego zakończeniem.

Wnioski. 1) Niedostateczna liczba lekarzy specjalistów w zakresie onkologii powoduje, że nie każda pacjentka ma szansę na wcześniejsze zdiagnozowanie i rozpoczęcie leczenia. 2) Regularne badania mogą przyczynić się do spadku liczby zgonów z powodu dwóch najgroźniejszych nowotworów kobiecych. 3) Rozpoznanie nowotworu raka piersi, szyjki macicy oraz jego skutki mają negatywny wpływ na psychikę kobiet, a zwłaszcza postrzeganie swojej kobiecości. W związkach, w których istniała silna więź uczuciowa przed chorobą kobiety, zauważono poprawę życia seksualnego. 4) Duże nakłady finansowe na programy profilaktyczne nie gwarantują zwiększenia wykrywalności nowotworów i spadku liczby zgonów.

Słowa kluczowe: profilaktyka, nowotwór, kobiecość

ABSTRACT THEIMPORTANCE OF CANCERS PROPHYLAXIS AMONG WOMEN

Introduction. Late detected breast and cervical cancer are two of the most dangerous cancers due to the therapeutic possibilities and high mortality rate of women. Conducted scientific research, prevention programs and social campaigns do not contribute to changes in the attitudes of Polish women who, do not report for examinations and thus, preclude the possibility of early diagnosis. Aim. The aim of the study is to analyze epidemiological data on the occurrence of cancer in women in Poland and to draw attention to the importance of prevention in this area.

Material and methods. For epidemiological analyzes, data from the National Cancer Registry, the Central Statistical Office and the Supreme Medical Chamber from the years 2014-2018 were prepared using descriptive methods.

Discussion. Every year the number of cancer deaths increases $(S A 0,2018)$. Prevention, despite financing from the state budget, did not bring the intended goal. More than half of the surveyed men claimed that women after mastectomy lose their attractiveness and those men would not start a new relationship with such women. Despite the fact that permanent, long-term partners accept the appearance of their partner after mastectomy, women are ashamed of their sexuality, what has its consequence in problems in the relationship or even the end of this relationship. 
Conclusions. 1) Insufficient number of specialists in the field of oncology results in the fact that not every patient has a chance to be early diagnosed and to early start the treatment. 2) Regular examinations may contribute to a decrease in deaths caused by two most dangerous female cancers. 3) Diagnosis of breast cancer, cervical cancer and its effects have a negative impact on the psyche of women, especially on the perception of their femininity. In relationships in which there was a strong emotional bond before the woman's disease, an improvement in sexual life was noted. Important factors affecting such relationship are: self-acceptance of a woman and her sense of attractiveness. 4) Large financial expenditures on preventive programs do not guarantee an increase in the detection of tumors nor a decrease in the number of deaths.

Key words: prevention, cancer, femininity

\section{INTRODUCTION}

Malignancies are relatively high mortality diseases occurring in every population. For many years both morbidity and mortality caused by malignancies have been increasing. They are the second leading cause of deaths in Poland (23.6\%). In 2015 over 163000 of new incidences were reported to the National Cancer Register and over 100000 deaths were confirmed for this reason. The most dangerous malignancies include breast cancer and cervical cancer which, when detected late, are hard to cure due to limited therapeutic possibilities and high degree of female mortality. Awareness of the existence of risks resulting from tumors is wide, although still neglected. Awareness-raising campaigns and persuading women to attend preventive checks do not bring the expected results. Consequently, early detection of cancer is not achieved and decrease in mortality does not happen. At the same time, greater cancer incidence is predicted due to the adverse environmental changes, climate changes, as well as ubiquitous chemical substances (e.g. preservatives), decreasing mental resilience and increasing pace of living, especially in case of women who fulfill numerous social roles. It should be noticed that including celebrities in preventive actions, or open talking about fighting with cancer may contribute to far-reaching changes in family life.

\section{AIM}

The aim of the study is to analyze epidemiological data on the occurrence of cancer in women in Poland and to draw attention to the importance of prevention in this area.

\section{MATERIALS AND METHODS}

For epidemiological analyzes, data from the National Cancer Registry, the Central Statistical Office and the Supreme Medical Chamber from the years 2014-2018 were prepared using descriptive methods.

\section{RESULTS}

In the years 2014-2018 in Poland 155000 of cancer incidences were registered and 93000 of deaths caused by them were confirmed annually [1]. Among the cancers, there are those characteristic for women. In the first place they include breast cancer and in the second - cervical cancer. One of the most frequent existing among women disease is breast cancer. In 2014 the percentage of new incidences was equal to $21.7 \%$, while in the following year it increased to $22.2 \%$. Comparing the proportion of cancer incidence to the proportion of mortality, this rate remained high and was equal to $13.9 \%$ in 2014 , while $14.1 \%$ in 2015 . Another example of the most frequent cancer in women is cervical cancer. Basing on the data analysis, decrease in morbidity to this cancer is noticeable (in 2014 it was 3.5\%, while in $2015-3.3 \%$ ), similarly to mortality - respectively: $4.4 \%$ and $3.5 \%$. The next cancer occurring in female population is ovarian cancer, wherein incidence percentage was equal to $4.7 \%$ (2014) and $4.6 \%$ (2015), while mortality rate $-6.2 \%$. In the same period the incidence proportion of colorectal cancer was $6.2 \%$. Analyzing mortality, the proportion was significantly higher and was equal to $11.6 \%$ in 2014 and $11.9 \%$ in 2015 (Tab. $1,2)[2,3,4]$.

\section{Tab. 1. Cancers morbidity among women}

\begin{tabular}{|l|c|c|c|}
\hline \multirow{2}{*}{\multicolumn{1}{|c|}{ Type of cancer }} & \multicolumn{3}{|c|}{ Years } \\
\cline { 2 - 4 } & $\mathbf{2 0 1 4}$ & $\mathbf{2 0 1 5}$ & $\mathbf{2 0 1 6}$ \\
\hline Breast cancer & $21.7 \%$ & $22.2 \%$ & $22.8 \%$ \\
\hline Cervical cancer & $\mathbf{3 . 5} \%$ & $\mathbf{3 . 3} \%$ & $\mathbf{3 . 2} \%$ \\
\hline Lung and bronchus cancer & $9.2 \%$ & $9.2 \%$ & $9.5 \%$ \\
\hline Thyroid cancer & $3.3 \%$ & $3.6 \%$ & $4.1 \%$ \\
\hline Skin cancer & $\mathbf{9 . 1} \%$ & $\mathbf{8 . 2} \%$ & $\mathbf{7 . 8} \%$ \\
\hline Rectal cancer & $\mathbf{2 . 9} \%$ & $\mathbf{2 . 8} \%$ & $\mathbf{2 . 7 \%}$ \\
\hline Stomach cancer & $\mathbf{2 . 5} \%$ & $\mathbf{2 . 4 \%}$ & $\mathbf{2 . 3} \%$ \\
\hline Ovarian cancer & $\mathbf{4 . 7} \%$ & $\mathbf{4 . 6 \%}$ & $\mathbf{4 . 6 \%}$ \\
\hline Colorectal cancer & $6.2 \%$ & $6.2 \%$ & $6.3 \%$ \\
\hline Endometrial cancer & $7.4 \%$ & $7.6 \%$ & $7.7 \%$ \\
\hline
\end{tabular}

Source: 0 wn elaboration on the basis of: [2].

Tab. 2. Cancers mortality among women

\begin{tabular}{|l|c|c|}
\hline \multirow{2}{*}{\multicolumn{1}{|c|}{ Type of cancer }} & \multicolumn{2}{c|}{ Years } \\
\cline { 2 - 3 } & $\mathbf{2 0 1 4}$ & $\mathbf{2 0 1 5}$ \\
\hline Lung cancer & $\mathbf{1 7 . 2} \%$ & $\mathbf{1 6 . 6 \%}$ \\
\hline Breast cancer & $13.9 \%$ & $14.1 \%$ \\
\hline Colorectal cancer & $11.6 \%$ & $11.9 \%$ \\
\hline Ovarian cancer & $6.2 \%$ & $6.2 \%$ \\
\hline Pancreatic cancer & $5.9 \%$ & $5.4 \%$ \\
\hline Cervical cancer & $\mathbf{4 . 4 \%}$ & $\mathbf{3 . 5} \%$ \\
\hline Stomach cancer & $3.8 \%$ & $4.1 \%$ \\
\hline Liver cancer & $2.0 \%$ & $2.0 \%$ \\
\hline Bladder cancer & $1.8 \%$ & $1.8 \%$ \\
\hline Esophageal cancer & $0.8 \%$ & $0.7 \%$ \\
\hline
\end{tabular}

Source: 0 wn elaboration on the basis of: $[3,4]$ 
Women's morbidity to skin cancers has significantly decreased, what may be a result of the multi-annual campaigns raising awareness of the consequences of long-term sunbathing, both in a natural way and artificially, but also a result of using sunscreens. Slight decrease was noticed in the incidence of stomach cancer, rectal cancer, as well as cervical cancer and ovarian cancer. Still observable is increase in incidence of breast cancer, endometrial cancer, lung cancer, thyroid cancer, colorectal cancer [2].

Cancer mortality among women in Poland remained high and hardly shows declining trend. The cancer with the highest mortality rate in 2014 was lung cancer (17.2\%), wherein in $2015-16.6 \%$ of deaths were recorded. In the second place there was breast cancer, whose mortality rate in 2015 increased to $14.1 \%$. This rate in case of ovarian cancer (6.2\%), liver cancer (2\%) and bladder cancer (1.8\%) remained stable. Proportion of mortality concerning colorectal cancer and stomach cancer increased in 2015, while this proportion in case of pancreatic cancer $(0.5 \%)$, cervical cancer $(1.1 \%)$ and esophageal cancer $(0.1 \%)$ decreased (Tab. 2) $[3,4]$.

Among the causes of cancer incidence they are mentioned smoking and chewing tobacco, which increases chances of getting sick. Not only harmful effects of tobacco are underlined, but also, maybe above all, of substances included in cigarettes. Similarly, alcohol, by reducing immunity and by topical effect, increases the risk of some cancers incidence. It was observed that simultaneous drinking alcohol and smoking cigarettes increases the risk many times more than only one of those factors. Another carcinogen is UV radiation, whose influence increases the risk of skin cancers occurrence. As prevention, avoiding long-term exposition, using sunscreens and avoiding solarium were recommended. Other indications in cancer prevention include: maintaining stable, correct body mass, eating fresh vegetables and fruit, reducing eating of red meat. Definitely all the out-of-date products or those covered with mould, as well as burnt ones should be avoided. It is worth using vaccines against viruses which may cause development of certain types of tumors, e.g. vaccine against human papilloma virus (HPV) which can lead to development of cervical cancer, or vaccine against hepatitis B (as prevention against hepatocellular carcinoma). Factors with proved cancerogenic character such as asbestos or aromatic compounds should be avoided [1]. Risk factors having a carcinogenic influence are listed in Table 3.

Breast cancer constitutes the biggest number of incidences in women, approximately $1 / 5$ of all cancer incidences in women, while colorectal cancers are the second most frequent tumors. In the third place there is a lung cancer. Subsequently, there are endometrial cancers, ovarian cancers, cervical cancers, kidney cancers, stomach cancers and thyroid cancer (Tab. 4). By contrast, lung cancer is the most frequent cause of deaths among women, wherein it is every sixth cause of cancer deaths. According to data from 2017, breast cancer was cause of $15 \%$ deaths, while colorectal cancer - $12 \%$ [6]. Other tumors which were the causes of women's deaths were: ovarian cancer, pancreatic cancer, cervical cancer, stomach cancer, liver cancer, bladder cancer and esophageal cancer (Tab. 4).
It is worth comparing the position of Poland and the countries with the highest mortality rate concerning certain type of cancer. Analyzing deaths of persons with lung cancer, Polish women take the $16^{\text {th }}$ place, however when including men - Poland takes the $7^{\text {th }}$ position (Tab. 4). Frequency of cancer deaths depending on age is derivative of incidences occurrence in certain age groups. Most of deaths caused by malignant cancers happens after 60 year of age [7].

\section{Tab. 3. Cancer risk factors}

\begin{tabular}{|c|c|}
\hline Tumor & Risk factors common for all tumors \\
\hline $\begin{array}{l}\text { 1. } \begin{array}{l}\text { Breast } \\
\text { tumor } \\
\text { 2. } \\
\text { Colorectal } \\
\text { tumor }\end{array} \\
\text { 3. Malignant } \\
\text { lung tumor } \\
\text { 4. Endometrial } \\
\text { tumor } \\
\text { 5. Ovarian } \\
\text { tumor } \\
\text { 6. Cervical } \\
\text { tumor } \\
\text { 7. Kidney } \\
\text { tumor } \\
\text { 8. Stomach } \\
\text { tumor } \\
\text { 9. Thyroid } \\
\text { tumor } \\
\text { 10. Pancreatic } \\
\text { tumor }\end{array}$ & $\begin{array}{l}\text { - age (between 50. and 69. year of age), } \\
\text { - } \text { sex, } \\
\text { - genetic factors (e.g. BRCA1 and BRCA2), } \\
\text { - } \text { family history, } \\
\text { early menstruation (before the 12. year of age) and } \\
\text { - lack of children or child after the age of } 35 \text { years, } \\
\text { - use of hormonal contraception or hormone } \\
\text { replacement therapy, } \\
\text { - early age of sexual initiation, } \\
\text { - number of sexual partners, } \\
\text { - hormonal disorders } \\
\text { - childlessness, ineffective ovulation stimulation, } \\
\text { - other tumors in the past, } \\
\text { - ionizing radiation, } \\
\text { - environmental factors, chemicals used in industry, } \\
\text { - obesity, } \\
\text { - alcohol, cigarettes, } \\
\text { - lack of physical activity, } \\
\text { - inappropriate diet, } \\
\text { - low socioeconomic status. }\end{array}$ \\
\hline
\end{tabular}

Source: 0 wn elaboration on the basis of: [5].

Tab. 4. Number of cancer deaths in Poland and in the world in 2017

\begin{tabular}{|c|c|c|c|c|c|}
\hline \multirow{2}{*}{$\begin{array}{l}\text { Type of } \\
\text { cancer }\end{array}$} & \multicolumn{2}{|c|}{$\begin{array}{l}\text { Number of women's } \\
\text { deaths in Poland }\end{array}$} & \multirow{2}{*}{$\begin{array}{l}\text { Country with } \\
\text { the highest } \\
\text { number of } \\
\text { women's } \\
\text { deaths }\end{array}$} & \multicolumn{2}{|c|}{$\begin{array}{l}\text { Total number of deaths } \\
\text { in the world }\end{array}$} \\
\hline & Ranking & $\begin{array}{l}\text { Death rate } \\
\text { per } 100,000\end{array}$ & & Ranking & $\begin{array}{c}\text { Death rate } \\
\text { per } 100,000\end{array}$ \\
\hline $\begin{array}{l}\text { Lung } \\
\text { cancer }\end{array}$ & 16 & 18.27 & $\begin{array}{c}\text { North Korea } \\
-36.60 \% \\
\end{array}$ & 7 & 34.26 \\
\hline $\begin{array}{l}\text { Breast } \\
\text { cancer }\end{array}$ & 107 & 15.36 & $\begin{array}{l}\text { Tonga - } \\
38.76 \% \\
\end{array}$ & $\begin{array}{l}\text { Lack of } \\
\text { data }\end{array}$ & Lack of data \\
\hline $\begin{array}{l}\text { Colorectal } \\
\text { cancer }\end{array}$ & 48 & 11.91 & $\begin{array}{c}\text { Grenada - } \\
23.70 \% \\
\end{array}$ & 29 & 16.55 \\
\hline $\begin{array}{l}\text { Ovarian } \\
\text { cancer }\end{array}$ & 11 & 7.77 & $\begin{array}{c}\text { Kazakhstan - } \\
13.62 \% \\
\end{array}$ & $\begin{array}{l}\text { Lack of } \\
\text { data }\end{array}$ & Lack of data \\
\hline $\begin{array}{l}\text { Pancreatic } \\
\text { cancer }\end{array}$ & 35 & 6.12 & $\begin{array}{c}\text { Kazakhstan - } \\
15.80 \% \\
\end{array}$ & 35 & 7.43 \\
\hline $\begin{array}{l}\text { Cervical } \\
\text { cancer }\end{array}$ & 123 & 5.32 & $\begin{array}{c}\text { Mozambique } \\
-49.65 \%\end{array}$ & $\begin{array}{l}\text { Lack of } \\
\text { data }\end{array}$ & Lack of data \\
\hline $\begin{array}{l}\text { Stomach } \\
\text { cancer }\end{array}$ & 89 & 4.32 & $\begin{array}{c}\text { Mongolia - } \\
18.46 \%\end{array}$ & 67 & 7.35 \\
\hline $\begin{array}{l}\text { Liver } \\
\text { cancer }\end{array}$ & 149 & 2.42 & $\begin{array}{c}\text { Mongolia - } \\
65.01 \% \\
\end{array}$ & 155 & 3.16 \\
\hline $\begin{array}{l}\text { Bladder } \\
\text { cancer }\end{array}$ & 45 & 1.69 & $\begin{array}{l}\text { Mali- } \\
4.83 \% \\
\end{array}$ & 13 & 4.79 \\
\hline $\begin{array}{l}\text { Esophageal } \\
\text { cancer }\end{array}$ & 108 & 0.79 & $\begin{array}{c}\text { Malawi- } \\
20.39 \%\end{array}$ & 99 & 2.25 \\
\hline
\end{tabular}

Source: Own elaboration on the basis of: [6]. 
In tumors prevention of women above 20 years of age the most important examination is gynecological examination and cytology, recommended once a year. A significant element also constitutes breast self-examination performed once a month, which helps in early detection of tumor and faster diagnostics [8]. Women after the age of 40 should control thyroid hormone levels and undergo other vital for health examinations, which are presented in Table 5.

\begin{tabular}{|c|c|c|}
\hline Age & Examination & Frequency \\
\hline $20+$ & $\begin{array}{l}\text { Gynecological examination and cytology } \\
\text { Transvaginal ultrasound } \\
\text { Breast self-examination }\end{array}$ & $\begin{array}{l}\text { Once a year } \\
\text { Once every } 2 \text { years } \\
\text { Once a month }\end{array}$ \\
\hline $30+$ & $\begin{array}{l}\text { Gynecological examination and cytology } \\
\text { Transvaginal ultrasound } \\
\text { Breast self-examination }\end{array}$ & $\begin{array}{l}\text { Once a year } \\
\text { Once every } 2 \text { years } \\
\text { Once a month }\end{array}$ \\
\hline $40+$ & $\begin{array}{l}\text { Gynecological examination and cytology } \\
\text { Transvaginal ultrasound } \\
\text { Breast scan and mammography } \\
\text { Thyroid-stimulating hormone test } \\
\text { Breast self-examination }\end{array}$ & $\begin{array}{l}\text { Once a year } \\
\text { Once every } 2 \text { years } \\
\text { Once every } 2 \text { years } \\
\text { Once a year } \\
\text { Once a month }\end{array}$ \\
\hline $50+$ & $\begin{array}{l}\text { Gynecological examination, cytology } \\
\text { and reproductive organs ultrasound } \\
\text { Mammography } \\
\text { Determination of sex hormones in blood } \\
\text { Thyroid-stimulating hormone test } \\
\text { Breast self-examination } \\
\text { Colonoscopy } \\
\text { Densitometry testing }\end{array}$ & $\begin{array}{l}\text { Once a year } \\
\text { Once every two years } \\
\text { Once every few years } \\
\text { Once a year } \\
\text { Once a month } \\
\text { Once every } 10 \text { years } \\
\text { Once every } 10 \text { years }\end{array}$ \\
\hline
\end{tabular}

Source: Own elaboration on the basis of: [9].

Apart from examinations enumerated in Table 3, women should also undergo basic preventive, ophthalmological and dental examinations. Effectiveness of the conducted examinations is influenced by their regularity. Gynecological examinations and cytology should be performed once a year after 20 years of age. A significant recommendation is also breast self-examination, which women should make once a month between the $6^{\text {th }}$ and $9^{\text {th }}$ day of the cycle, while after the menopause in one chosen day of the month. There also exist preventive programs addressed to women, e.g. "Breast cancer and cervical cancer prevention programme" and " Prenatal screening programme" [9].

During three years the number of incidences of breast cancer among women increased by $0.9 \%$ (Tab. 1). Upward trend was also visible in case of morbidity to thyroid cancer $(0.8 \%)$. What could be observed, was significant decrease of skin cancer incidence, whose number was smaller by $1.3 \%$. The number of malignant cancers incidences in the general population in 2016 was equal to 164140 [9].

At present in Poland there are 13221003 women aged $20-85+[10]$, who should have provided access to an oncologist. The number of doctors with this specialization is only 1831 [11], which means that probably not every patient will have access to a specialist (Tab. 6).

Every year many women in Poland and in the world are diagnosed with the above mentioned cancers, which take their toll. Early diagnosis allows for implementation of treatment, thanks to which recovery is possible.
Tab. 6. Comparison of the number of patients per number of oncologists in Poland

\begin{tabular}{|l|c|c|}
\hline \multicolumn{1}{|c|}{ Specialization } & $\begin{array}{c}\text { Number of } \\
\text { doctors }\end{array}$ & $\begin{array}{c}\text { Percentage of specialists } \\
\text { per 1 patient }\end{array}$ \\
\hline Surgical oncology & 878 & $0.0007 \%$ \\
\hline Clinical oncology & 953 & $0.0007 \%$ \\
\hline Total & 1831 & $0.0014 \%$ \\
\hline
\end{tabular}

Source: Own elaboration on the basis of: $[10,11]$.

\section{DISCUSSION}

Breast cancer is the most frequently diagnosed tumor among women in Poland. It constitutes approximately 23\% of all cancer incidences and about $14 \%$ of deaths caused by cancer. Every year the cancer is recognized in 1.5 million women in the world, and approximately 400000 of them die. The cancer the most frequently occurs in the West Europe countries, Russia, Argentina and Uruguay, while the least frequently - in South Asia, Peru, Bolivia and Chile. The biggest number of incidences is recorded between 50 and 70 years of age. The genes mutation BRCA1/2 is one of the most risky genetic factors. One of the symptoms of cancer may be palpable during breast self-examination lumps, which may help early detection, doctor's diagnosis and beginning of treatment [12].

Cervical cancer is presently the third most frequent cancer among women in the world. Annually it affects approximately 500000 women, out of which 233000 die. The incidence peak is between 45 and 59 years of age. Poland belongs to the group of countries with average morbidity to this cancer. However, the country has one of the highest incidence and mortality rates in Europe. Early stage of cervical cancer does not usually show any symptoms, that is why regular cytology is so vital. Nowadays it is considered that the most significant risk factor for development of cervical cancer is infection of cervical epithelial cells with the human papilloma virus (HPV).

Unfortunately, constant progress in medicine does not have influence on significant decrease of women's deaths due to malignant diseases. It seems that the crucial meaning has an attitude of women towards preventive examinations, while it must be noticed that prophylaxis still is not a priority for them. Awareness among women is constantly low, that is why it needs to be continually increased [13].

In case of diagnosing cancer in a woman, therapeutic actions are planned, including one treatment method or combination therapy, taking into account use of chemotherapy, radiotherapy, hormonotherapy, and operation. When it comes to breast cancer or genital organs cancer, they are mostly also connected with radical or conserving surgical treatment [14].

In patient's recovery and return to social activity, an important role is played by woman's psyche. Particularly in case of breast surgical treatment, woman's self-acceptance is vital, including acceptance of carnality, exposing femininity and experiencing an intimate relationship with a partner (bodily self) [15].

In the meantime, over half of the men taking part in the research "Male attitude towards women after mastectomy" 
claimed that they accept breast amputation, however women after this surgery lose their attractiveness and the men would not start a new relationship with them. It is uplifting that over $90 \%$ of the surveyed men declare that they do not think less of their partners' physical attractiveness after the mastectomy. They are eager to support and help their partners during the time of recovery [16].

In the course of the study conducted in the Clinic of Oncology of the Jagiellonian University Medical College from March to December 2015 among women aged 18-65 years old after mastectomy or conservative surgery, the following results were diagnosed: acceptance of own carnality defined by a degree of woman's satisfaction with her appearance and current figure, way of experiencing self in an intimate, physical relationship with a man, acceptance and exposing femininity, attitude towards food intake and maintaining certain body weight [15]. The study found out that surgical treatment of breast cancer is in close connection with the way of experiencing own body by the surveyed women.

After mastectomy or breast conservative surgery there is a similar risk of lowered acceptance of own carnality and worsening of experiencing intimate relationship with a partner, while patients more expose their femininity, what may reflect compensation mechanism of missing or mutilated attribute of female identification (breasts) and rebuilding of self-esteem. No changes concerning attitude of women after oncological breast surgery towards eating and body weight were observed [15].

Studies concerning sexual satisfaction of women after mastectomy were run within the framework of the national project "Sexuality of women after mastectomy", led by prof. Zbigniew Lew-Starowicz by the counselling centers and at the oncological wards in the Małopolskie and Sląskie provinces and in the Amazon Women Associations, in the group of patients aged 18-65 years old [17]. As a result of the study, it was found out that women after the period of 18 months from the radical mastectomy assessed their sexuality worse than women after the period of 5 years from the breasts removal surgery (significant connection with the period of time necessary to getting used to a new situation and accepting mutilation). In contrast, male partners in most of the sexual contacts achieved pleasure and satisfaction. Women being 18 months after the surgery stated that their sexual intercourses take place less frequently than before the cancer detection, while patients who are 5 years from the surgery described the frequency of their sexual intercourses as sufficient. The quality of life significantly weakens the feeling of fear and mood disorders regardless of the period of time after the mastectomy [17].

In the years 2005-2008 in the Oncology Clinic at the St. Leszczynski Hospital in Katowice and in the Silesian League to Fight Against Cancer in Katowice, there were conducted studies concerning sexual functioning in marriage and self-image of women after the treatment of endometrial cancer from the perspective of the patients and their healthy husbands. The study included marriage couples in which wives finished basic treatment of endometrial cancer at least a half year before the psychological consultation [18].
As a result of the study, it was found out that: there are great discrepancies between an assessment of sexual functioning in marriage, self-esteem and image of woman from the perspective of women treated with endometrial cancer and from the perspective of their husbands. It points to the areas of danger in the functioning of the marriage resulting from lack of good, open communication between the partners. The effect of the communication disorders in marriages is incomplete knowledge of changes in the feelings, thoughts, behaviors of wives, triggered by treatment of endometrial cancer. Women after hysterectomy have significantly lowered self-esteem, as well as emotional, cognitive and behavioral difficulties in the sexual functioning in marriage. As a result, they avoid touching, nudity, treat sex as a duty. They compensate an incomplete, in their view, role of the wife with good functioning in the remaining social roles (mother, worker). Their partners do not notice problems in the sexual life [18].

In spite of the awareness of the partner's health condition and willingness to accompany her in during disease, part of the relationships falls apart after the end of the therapy. An example may be Kylie Minogue who, just after winning the battle against breast cancer, separated from her partner, who, according to what was said, had supported her during the disease. According to the studies of Macmillan Cancer Support, every seventh relationship falls apart as a result of malignant disease of one of the partners [19]. As the research conducted at the University of Washington, the Stanford University and the University of Utah showed, men averagely seven times more often break up with their partners diagnosed with cancer or multiple sclerosis, than women when it comes to their partners with similar diagnosis. The percentage of separations or divorces amounted to almost $21 \%$ in case of chronic illness of a woman, while $3 \%$ in case of man's illness [20]. From the psychological point of view, the reasons standing behind such separations may be a desire for mutual protection and consequently - hiding own feelings, what leads to creating distance in the relationship. Also, change of roles, displacement of the center of responsibility for livelihood and consequently feeling burden by a healthy person, may give a sense of disappointing the partner. What can be frequently heard from the people who separate from an ill partner is "That's beyond me" [19], and from their partners: "I was ill but it was him who broke down" [20]. Some men separate just after diagnosing cancer in their partner, part of men initially support their partners but when a woman feels unattractive and avoids intimate relations, a man drifts apart, withdraws and finds comfort in an affair, not leaving the partner, but simultaneously waiting for her suggestion to fall apart. It becomes limited to saying "He could not cope with my disease, our relationship was not strong enough and it would surely fall apart sooner or later" [19]. It happens that it is an affair with a mutual friend, what additionally deepens sorrow of an ill woman and worsens her self-esteem [20]. According to Sabina Sadecka, a psychologist and psychotherapist who works with patients in the Rak Off Foundation in Poznań, equally frequent are psychological separations, in which partners pretend to be 
together, while each of them is dramatically lonely. Similarly, Katarzyna Cieślak, psychooncologist cooperating with the Federation of Amazon Associations emphasizes that cancer is a test for marriage, often highlighting those things, which did not function properly before. The crisis is frequently connected with a change in woman's appearance, or with lack of intimate relations [20].

The relations woman - man are different when partners meet each other during or after the end of treatment. Especially when woman's previous relationship fell apart due to cancer. The next partner, aware of the possibility of relapses, usually supports his partner, however the couples also use the offered help, e.g. the family counselling. Thanks to that, the relationship has a chance to develop and becomes durable and strong. Departure of a partner may lead to suicide attempts, that is why mutual support of women in various kinds of associations, as well as permanent access to specialists from the field of psychology is crucial, as women struggling with cancer should not be lonely. However, what is the most important, is the courage of the women to admit to themselves that they need help [19].

In the Great Britain an increase in genetic tests was referred to as "Angelina Jolie effect" by doctors. It was confirmed by the British NHS statistics, as double growth of tests for the presence of BRCA1 and BRCA2 gene mutations responsible for breast and ovarian cancer was recorded [21]. Even if the given source is not very reliable, it undoubtedly persuades the readers to take preventive actions. Nowadays, in the age of media, an essential is support of preventive actions from testimonies of celebrities who won the fight against cancer and openly admit it, such as Kylie Minogue, Anastacia, Sheryl Crow, Cynthia Nixon, Christina Applegate, Jaclyn Smith, who actively participate in campaigns promoting preventive examinations. Breast cancer did not also spare the woman whose breasts have always been admired, that is Brigitte Bardot. The following Polish celebrities also won the fight against cancer: Irena Santor, Beata Kawka, Krystyna Kofta, Marzena Sienkiewicz, Anna Seniuk or Ewa Minge (who actively cooperates with the Amazon Associations). All those women are engaged in promotion of preventive examinations. It must be noticed that some famous beauties underwent mastectomy or hysterectomy in order to avoid tumor, due to the fact that they belonged to the group of high risk. They include, among others, Angelina Jolie and Christina Applegate.

\section{CONCLUSIONS}

1. Insufficient number of specialists in the field of oncology results in the fact that not every patient has a chance to be early diagnosed and to start the treatment. Consequently, it leads to high mortality among women, which does not show downward trend in Poland.

2. Regular examinations, e.g. cytology or breast self-examination may contribute to a decrease in deaths caused by two most dangerous female cancers.

3. Diagnosis of breast cancer, cervical cancer and its effects have a negative impact on the psyche of women, especially on the perception of their femininity. In relationships in which there was a strong emotional bond before the woman's disease, an improvement in sexual life was noted. Important factors affecting such relationship are: self-acceptance of a woman and her sense of attractiveness.

4. Large financial expenditures on preventive programs do not guarantee an increase in the detection of tumors nor a decrease in the number of deaths.

\section{SUMMARY}

Tumors are frequent cause of deaths in Poland and in the world. The most often ones encountered in women include: breast cancer, lung cancer, endometrial cancer and colorectal cancer. There are numerous factors increasing the risk of malignancy, e.g. age, genetic factors, or alcohol and smoking. In order to improve the chances for effective treatment, the cancer needs to be early detected. That is why women should regularly undergo preventive examinations, such as: breast self-examinations, breast scanning, mammography, cytology and other, according to the medical examinations calendar recommended for women. Unfortunately, despite many preventive programs, the percentage of cancer diseases among women is still increasing. Also mortality rarely shows constant downward trend, that is why prophylaxis, examinations, healthy lifestyle and continuous educational and medial actions are significant. 


\section{Znaczenie profilaktyki nowotworów wśród kobiet}

\section{WPROWADZENIE}

Nowotwory złośliwe są chorobami o stosunkowo dużej śmiertelności, występującymi w każdej populacji. Przez wiele lat zarówno zachorowalność, jak i umieralność z powodu złośliwych chorób nowotworowych rosła. Stanowią drugą co do przyczyn zgonów w Polsce $(23,6 \%)$. W 2015 roku do rejestru nowotworów złośliwych zgłoszono ponad 163 tys. nowych zachorowań i stwierdzono ponad 100 tys. zgonów z tego powodu. Do najgroźniejszych $\mathrm{z}$ nich należą rak piersi i szyjki macicy, które późno wykryte są trudne do wyleczenia ze względu na ograniczone możliwości terapeutyczne oraz wysoki stopień umieralności kobiet. Świadomość istnienia zagrożeń wynikających z nowotworów jest powszechna, lecz wciąż lekceważona. Prowadzone kampanie społeczne i zachęcanie do badań profilaktycznych nie przynoszą oczekiwanych rezultatów. W konsekwencji nie dochodzi do wczesnego wykrycia nowotworu i spadku umieralności. Równocześnie prognozowana jest większa zachorowalność na nowotwory, ze względu na niekorzystne zmiany środowiska naturalnego, zmiany klimatyczne, a także wszechobecną chemię (np. konserwanty), coraz mniejszą odporność psychiczną i coraz większe tempo życia ludzi, a zwłaszcza kobiet pełniących wiele funkcji społecznych. Zauważyć należy, że włączanie się celebrytek w akcje profilaktyczne, czy też otwarte mówienie o walce $z$ nowotworem, może przyczynić się do zwiększenia zainteresowania kobiet badaniami profilaktycznymi. Jest to szczególnie ważne, gdyż nawet wygrana walka $z$ nowotworem może przyczynić się do daleko idących zmian w życiu rodzinnym.

\section{CEL PRACY}

Celem pracy jest analiza danych epidemiologicznych dotyczących występowania nowotworów u kobiet w Polsce oraz zwrócenie uwagi na znaczenie profilaktyki w tym zakresie.

\section{MATERIAŁ I METODA}

Do analizy epidemiologicznej wykorzystano dane z Krajowego Rejestru Nowotworów, Głównego Urzędu Statystycznego oraz Naczelnej Izby Lekarskiej za lata 2014-2018 opracowane za pomocą metody opisowej.

\section{WYNIKI}

W Polsce w latach 2014-2018 odnotowano 155 tysięcy zachorowań na nowotwory i 93 tysiące zgonów z ich powodu rocznie [1]. Wśród nowotworów można wyróżnić te, które są charakterystyczne dla kobiet. Należą do nich na pierwszym miejscu rak piersi i na drugim rak szyjki macicy. Jednym z najczęściej występujących zachorowań wśród kobiet pozostał rak piersi. W 2014 roku odsetek nowych zachorowań wynosił 21,7\%, w kolejnym roku wzrósł do 22,2\%. Porównując odsetek zachorowań do odsetka umieralności, wskaźnik ten pozostał wysoki i wynosił 13,9\% w 2014, zaś 14,1\% w 2015 roku. Kolejny przykład wśród najczęstszych zachorowań na nowotwory wśród kobiet to rak szyjki macicy. Z analizy danych wynika, że zachorowalność na ten nowotwór maleje (w 2014 było 3,5\%, a w 2015 - 3,3\%), podobnie jak umieralność odpowiednio: 4,4\% i 3,5\%. Następny nowotwór występujący w populacji kobiet to rak jajnika, przy czym odsetek zachorowań wynosił 4,7\% (2014 rok) i 4,6\% (2015 rok), a liczba zgonów - 6,2\%. W analogicznym okresie współczynnik zachorowalności na raka jelita grubego wynosił 6,2. Analizując umieralność, odsetek był znacznie wyższy i wynosił 11,6\% w 2014 i 11,9\% w 2015 (tab. 1, 2) [2, 3, 4].

\begin{tabular}{|l|c|c|c|}
\hline \multirow{2}{*}{ Tab. 1. Zachorowania na nowotwory wśród kobiet } \\
\hline \multirow{2}{*}{ Rodzaj nowotworu } & \multicolumn{3}{|c|}{ Lata } \\
\cline { 2 - 4 } & $\mathbf{2 0 1 4}$ & $\mathbf{2 0 1 5}$ & $\mathbf{2 0 1 6}$ \\
\hline Rak piersi & $21,7 \%$ & $22,2 \%$ & $22,8 \%$ \\
\hline Rak szyjki macicy & $\mathbf{3 , 5} \%$ & $\mathbf{3 , 3} \%$ & $\mathbf{3 , 2} \%$ \\
\hline Rak płuca i oskrzela & $9,2 \%$ & $9,2 \%$ & $9,5 \%$ \\
\hline Rak tarczycy & $\mathbf{3 , 3} \%$ & $\mathbf{3 , 6} \%$ & $\mathbf{4 , 1} \%$ \\
\hline Rak skóry & $\mathbf{9 , 1} \%$ & $\mathbf{8 , 2} \%$ & $\mathbf{7 , 8} \%$ \\
\hline Rak odbytnicy & $\mathbf{2 , 9} \%$ & $\mathbf{2 , 8} \%$ & $\mathbf{2 , 7} \%$ \\
\hline Rak żołądka & $\mathbf{2 , 5} \%$ & $\mathbf{2 , 4} \%$ & $\mathbf{2 , 3} \%$ \\
\hline Rak jajnika & $\mathbf{4 , 7} \%$ & $\mathbf{4 , 6} \%$ & $\mathbf{4 , 6} \%$ \\
\hline Rak jelita grubego & $\mathbf{6 , 2} \%$ & $\mathbf{6 , 2} \%$ & $\mathbf{6 , 3} \%$ \\
\hline Rak trzonu macicy & $\mathbf{7 , 4} \%$ & $\mathbf{7 , 6} \%$ & $\mathbf{7 , 7} \%$ \\
\hline
\end{tabular}

Źródło: Opracowanie własne na podstawie: [2].

Tab. 2. Umieralność na nowotwory wśród kobiet

\begin{tabular}{|l|c|c|}
\hline \multirow{2}{*}{\multicolumn{1}{c|}{ Rodzaj nowotworu }} & \multicolumn{2}{c|}{ Lata } \\
\cline { 2 - 3 } & $\mathbf{2 0 1 4}$ & $\mathbf{2 0 1 5}$ \\
\hline Rak płuc & $\mathbf{1 7 , 2} \%$ & $\mathbf{1 6 , 6 \%}$ \\
\hline Rak piersi & $13,9 \%$ & $14,1 \%$ \\
\hline Rak jelita grubego & $11,6 \%$ & $11,9 \%$ \\
\hline Rak jajnika & $6,2 \%$ & $6,2 \%$ \\
\hline Rak trzustki & $5,9 \%$ & $5,4 \%$ \\
\hline Rak szyjki macicy & $\mathbf{4 , 4 \%}$ & $\mathbf{3 , 5 \%}$ \\
\hline Rak żołądka & $3,8 \%$ & $4,1 \%$ \\
\hline Rak wątroby & $2,0 \%$ & $2,0 \%$ \\
\hline Rak pęcherza moczowego & $1,8 \%$ & $1,8 \%$ \\
\hline Rak przełyku & $0,8 \%$ & $0,7 \%$ \\
\hline
\end{tabular}

Źródło: Opracowanie własne na podstawie: $[3,4]$. 
Zachorowalność kobiet na nowotwory skóry zmalała znacząco, co może być skutkiem wieloletnich kampanii uświadamiających konsekwencje wynikające $\mathrm{z}$ długotrwałego opalania się, zarówno w sposób naturalny, jak i sztuczny, ale też stosowania filtrów ochronnych. Niewielki spadek zauważono w zachorowalności na raka żołądka, odbytnicy, a także raka szyjki macicy i jajnika. Nadal obserwuje się wzrost zachorowalności na raka piersi, trzonu macicy, płuc, tarczycy, jelita grubego [2].

Umieralność na nowotwory wśród kobiet w Polsce pozostała wysoka i raczej nie wykazuje tendencji spadkowej. Do nowotworów o największym odsetku zgonów w 2014 roku należał rak płuc (17,2\%), przy czym w roku 2015 odnotowano 16,6\% zgonów. Na drugim miejscu znajdował się rak piersi, którego odsetek umieralności w 2015 zwiększył się do 14,1\%, nowotwory jajnika (6,2\%), wątroby $(2 \%)$ i pęcherza moczowego $(1,8 \%)$ utrzymywała się na stałym poziomie. Odsetek umieralności na nowotwory jelita grubego i żołądka zwiększył się w roku 2015, natomiast zmalał odsetek zgonów z powodu raka trzustki (0,5\%), szyjki macicy (1,1\%) i przełyku $(0,1 \%)$ (tab. 2) $[3,4]$.

Jako jedną z przyczyn zachorowań na nowotwory podaje się palenie i żucie tytoniu, które zwiększa szanse na zachorowanie. Podkreśla się także nie tylko szkodliwe działanie tytoniu, ale też, a może przede wszystkim, substancji wchodzących w skład papierosów. Podobnie alkohol, poprzez obniżenie odporności oraz działanie miejscowe, zwiększa ryzyko zachorowania na pewne typy nowotworów. Zaobserwowano, że jednoczesne picie alkoholu i palenie papierosów powoduje zwiększenie ryzyka wielokrotnie bardziej niż tylko jeden z tych czynników. Kolejny czynnik rakotwórczy to promieniowanie UV, którego oddziaływanie zwiększa ryzyko powstania raków skóry. Jako profilaktykę zalecano unikanie długiej ekspozycji, stosowanie kremów z filtrem i unikanie solariów. Inne wskazówki w profilaktyce nowotworów to: utrzymanie stałej, właściwej masy ciała, spożywanie świeżych warzyw i owoców, ograniczenie spożywania czerwonego mięsa. Bezwzględnie należy unikać produktów nieświeżych lub pokrytych pleśnią, jak również spalonych. Warto stosować szczepionki przeciwko wirusom mogącym powodować rozwój pewnych typów nowotworów np. szczepionkę przeciwko wirusowi brodawczaka ludzkiego (HPV), mogącemu prowadzić do rozwoju raka szyjki macicy czy też przeciwko wirusowemu zapaleniu wątroby typu B (jako prewencja raka wątrobowo komórkowego). Należy unikać czynników o udowodnionym charakterze kancerogennym jak azbest czy związki aromatyczne [1]. Czynniki ryzyka mające wpływ kancerogenny zostały wymienione w tabeli nr 3.

Rak piersi to najwięcej, bo około 1/5 wszystkich zachorowań na nowotwory u kobiet, zaś nowotwory jelita grubego to drugi co do częstości nowotwór. Trzecie miejsce zajmuje rak płuca. W dalszej kolejności występują nowotwory trzonu macicy, jajnika, szyjki macicy, nerki, żołądka i tarczycy (tab. 4). Natomiast rak płuca to najczęstsza przyczyna zgonów wśród kobiet, przy czym co szósta przyczyna zgonów nowotworowych. Według danych z 2017 roku rak piersi był przyczyną 15\% zgonów, a raka jelita grubego 12\% [6]. Kolejnymi nowotworami, które były przyczyną zgonów kobiet były: rak jajnika, trzustki, szyjki macicy, żołądka, wątroby, pęcherza moczowego i przełyku (tab. 4). Warto porównać pozycję Polski i krajów o największym odsetku zgonów na dany nowotwór. Analizując zgony osób chorych na nowotwór płuc, polskie kobiety zajmują 16. miejsce, natomiast wliczając dodatkowo mężczyzn Polska jest na miejscu 7. (tab. 4).

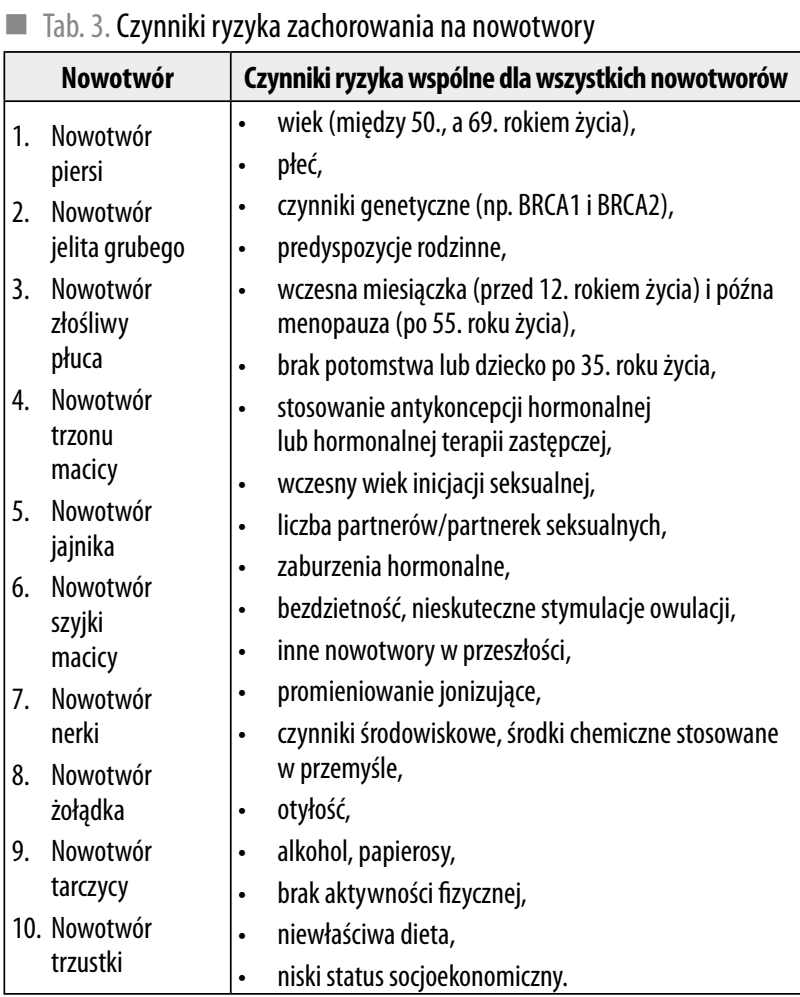

Źródło: Opracowanie własne na podstawie: [5].

Tab. 4. Liczba zgonów na nowotwory w Polsce i na świecie w 2017 roku

\begin{tabular}{|l|c|c|c|c|c|}
\hline \multirow{2}{*}{$\begin{array}{c}\text { Rodzaj } \\
\text { nowotworu }\end{array}$} & \multicolumn{2}{|c|}{$\begin{array}{c}\text { Ilość zgonów } \\
\text { kobiet w Polsce }\end{array}$} & \multicolumn{2}{c|}{$\begin{array}{c}\text { Kraj } \\
\text { o największej }\end{array}$} & \multicolumn{2}{|c|}{$\begin{array}{c}\text { Ilość zgonów ogółem } \\
\text { na świecie }\end{array}$} \\
\cline { 3 - 6 } & Ranking & $\begin{array}{c}\text { Wskaźnik } \\
\text { umieralności } \\
\text { ilości zgonów } \\
\text { kobiet }\end{array}$ & Ranking tys & $\begin{array}{c}\text { Wskaźnik } \\
\text { umieralności } \\
\text { na 100 tys }\end{array}$ \\
\hline Rak płuc & 16 & 18,27 & $\begin{array}{c}\text { Korea Pómocna- } \\
36,60 \%\end{array}$ & 7 & 34,26 \\
\hline Rak piersi & 107 & 15,36 & $\begin{array}{c}\text { Tonga - } \\
38,76 \%\end{array}$ & $\begin{array}{c}\text { Brak } \\
\text { danych }\end{array}$ & Brak danych \\
\hline $\begin{array}{l}\text { Rak jelita } \\
\text { grubego }\end{array}$ & 48 & 11,91 & $\begin{array}{c}\text { Grenada - } \\
23,70 \%\end{array}$ & 29 & 16,55 \\
\hline Rak jajnika & 11 & 7,77 & $\begin{array}{c}\text { Kazachstan- } \\
13,62 \%\end{array}$ & $\begin{array}{c}\text { Brak } \\
\text { danych }\end{array}$ & Brak danych \\
\hline Rak trzustki & 35 & 6,12 & $\begin{array}{c}\text { Kazachstan- } \\
15,80 \%\end{array}$ & 35 & 7,43 \\
\hline $\begin{array}{l}\text { Rak szyjki } \\
\text { macicy }\end{array}$ & 123 & 5,32 & $\begin{array}{c}\text { Mozambik- } \\
49,65 \%\end{array}$ & $\begin{array}{c}\text { Brak } \\
\text { danych }\end{array}$ & Brak danych \\
\hline Rak żołądka & 89 & 4,32 & $\begin{array}{c}\text { Mongolia - } \\
18,46 \%\end{array}$ & 67 & 7,35 \\
\hline Rak wątroby & 149 & 2,42 & $\begin{array}{c}\text { Mongolia - } \\
65,01 \%\end{array}$ & 155 & 3,16 \\
\hline $\begin{array}{l}\text { Rak } \\
\text { pęcherza } \\
\text { moczowego }\end{array}$ & 45 & 1,69 & $\begin{array}{c}\text { Mali- } \\
4,83 \%\end{array}$ & 13 & 4,79 \\
\hline Rak przełyku & 108 & 0,79 & $\begin{array}{c}\text { Malawi- } \\
20,39 \%\end{array}$ & 99 & 2,25 \\
\hline
\end{tabular}

Źródło: Opracowanie własne na podstawie: [6]. 
Częstość zgonów nowotworowych w zależności od wieku jest pochodną występowania zachorowań w poszczególnych grupach wiekowych. Większość zgonów na nowotwory złośliwe występuje po 60. roku życia [7].

W profilaktyce nowotworów u kobiet od 20. roku życia najważniejsze badanie to badania ginekologiczne i cytologia zalecane do wykonywania raz w roku. Bardzo istotnym elementem jest również samobadanie piersi wykonywane raz w miesiącu, które pomaga we wcześniejszym wykryciu choroby i jej szybszej diagnostyce [8]. Po 40. roku życia kobiety powinny kontrolować poziom hormonów tarczycy oraz poddawać się innym ważnym dla zdrowia badaniom, które zaprezentowano w tabeli 5.

Tab. 5. Kalendarz badań profilaktycznych kobiet

\begin{tabular}{|c|c|c|}
\hline Wiek & Rodzaj badania & $\begin{array}{c}\text { Częstość } \\
\text { wykonywania } \\
\text { badania }\end{array}$ \\
\hline $20+$ & $\begin{array}{l}\text { Badanie ginekologiczne i cytologia } \\
\text { USG przezpochwowe narządów rodnych } \\
\text { Samobadanie piersi }\end{array}$ & $\begin{array}{l}\text { Raz w roku } \\
\text { Raz na } 2 \text { lata } \\
\text { Raz w miesiącu }\end{array}$ \\
\hline $30+$ & $\begin{array}{l}\text { Badanie ginekologiczne i cytologia } \\
\text { USG przezpochwowe narządów rodnych } \\
\text { Samobadanie piersi }\end{array}$ & $\begin{array}{l}\text { Raz w roku } \\
\text { Raz na } 2 \text { lata } \\
\text { Raz w miesiącu }\end{array}$ \\
\hline $40+$ & $\begin{array}{l}\text { Badanie ginekologiczne i cytologia } \\
\text { USG przezpochwowe narządów rodnych } \\
\text { USG piersi i mammografia } \\
\text { Badanie poziomu hormonów tarczycy } \\
\text { Samobadanie piersi }\end{array}$ & $\begin{array}{l}\text { Raz w roku } \\
\text { Raz na } 2 \text { lata } \\
\text { Raz na } 2 \text { lata } \\
\text { Raz w roku } \\
\text { Raz w miesiącu }\end{array}$ \\
\hline $50+$ & $\begin{array}{l}\text { Badanie ginekologiczne, cytologia oraz USG } \\
\text { narządów rodnych } \\
\text { Mammografia } \\
\text { Oznaczenie poziomu hormonów płciowych we krwi } \\
\text { Badanie poziomu hormonów tarczycy } \\
\text { Samobadanie piersi } \\
\text { Kolonoskopia } \\
\text { Badanie densytometryczne }\end{array}$ & $\begin{array}{l}\text { Raz w roku } \\
\text { Raz na } 2 \text { lata } \\
\text { Raz na kilka lat } \\
\text { Raz w roku } \\
\text { Raz w miesiącu } \\
\text { Raz na } 10 \text { lat } \\
\text { Raz na } 10 \text { lat }\end{array}$ \\
\hline
\end{tabular}

Źródło: Opracowanie własne na podstawie: [9].

Oprócz wymienionych w tabeli nr 5 badań, kobiety powinny też wykonywać podstawowe badania profilaktyczne, okulistyczne czy stomatologiczne. Na skuteczność wykonywania badań ma wpływ ich regularność. Badania ginekologiczne i cytologię powinno wykonywać się raz w roku od 20. roku życia. Ważną rzeczą jest również samobadanie piersi, które kobiety powinny wykonywać raz w miesiącu między 6. a 9. dniem cyklu, zaś po menopauzie w określony dzień miesiąca. Są również dostępne programy profilaktyczne skierowane do kobiet, np., „Program profilaktyki raka piersi i raka szyjki macicy” i „Program badań prenatalnych" [9].

W ciągu 3 lat liczba zachorowań na nowotwór piersi wśród kobiet wzrosła o 0,9\% (tab. 1). Tendencje wzrostowe obserwowano w przypadku zapadalności na raka tarczycy $(0,8 \%)$. Obserwuje się znaczący spadek zachorowań na raka skóry, którego liczba zmniejszyła się o 1,3\%. Liczba zachorowań na nowotwory złośliwe w populacji ogółem w roku 2016 wynosiła 164140 [9].

W Polsce jest obecnie 13221003 kobiet w wieku 20-85+ [10], które powinny mieć zapewniony dostęp do lekarza onkologa. Lekarzy o tej specjalizacji, którzy obecnie wykonują zawód jest tylko 1831 [11] co oznacza, że prawdopodobnie nie każda pacjentka będzie miała dostęp do specjalisty (tab. 6).

Tab. 6. Porównanie liczby pacjentek przypadających na lekarzy onkologów w Polsce

\begin{tabular}{|l|c|c|}
\hline \multicolumn{1}{|c|}{ Rodzaj specjalizacji } & $\begin{array}{c}\text { Lekarze } \\
\text { wykonujący } \\
\text { zawód }\end{array}$ & $\begin{array}{c}\text { 0dsetek specjalistów } \\
\text { przypadających } \\
\text { na 1 pajentkę }\end{array}$ \\
\hline Chirurgia onkologiczna & 878 & $0,0007 \%$ \\
\hline Onkologia kliniczna & 953 & $0,0007 \%$ \\
\hline Razem & 1831 & $0,0014 \%$ \\
\hline
\end{tabular}

Źródło: Opracowanie własne na podstawie: $[10,11]$

Co roku u wielu kobiet w Polsce i na całym świecie zdiagnozowane zostają powyższe nowotwory, które zbierają ogromne żniwo. Wczesna diagnoza pozwala na wprowadzenie leczenia, dzięki któremu wyleczenie z nowotworu będzie możliwe.

\section{DYSKUSJA}

Nowotwory piersi są najczęściej rozpoznawanym nowotworem wśród kobiet w Polsce. Stanowią około $23 \%$ wszystkich zachorowań i około $14 \%$ zgonów z tego powodu. Co roku nowotwór ten rozpoznaje się u 1,5 miliona kobiet na całym świecie, a około 400 tysięcy umiera $\mathrm{z}$ tego powodu. Najczęściej występuje on w krajach Europy Zachodniej, Rosji, Argentynie i Urugwaju. Najrzadziej w Azji Południowej, Peru, Boliwii i Chile. Najwięcej zachorowań odnotowuje się pomiędzy 50. a 70. rokiem życia. Mutacja genów BRCA1/2 jest jednym $\mathrm{z}$ najbardziej z ryzykownych czynników genetycznych. Jednym z objawów wystąpienia nowotworu mogą być wyczuwalne guzki podczas samobadania piersi, które może pozwolić na wczesne wykrycie, diagnozę lekarską i rozpoczęcie leczenia [12].

Rak szyjki macicy jest obecnie trzecim pod względem częstości zachorowań nowotworem u kobiet na świecie. Rocznie zapada na niego około 500 tysięcy kobiet, a umierają 233 tysiące. Szczyt zachorowań przypada na 45.-59. rok życia. Polska należy do krajów na świecie o średniej zachorowalności na ten nowotwór. Ma jednak jeden $\mathrm{z}$ najwyższych wskaźników zachorowalności i umieralności w Europie. Wczesne stadium raka szyjki macicy zazwyczaj nie daje żadnych objawów, dlatego tak bardzo ważne jest regularne, wykonywanie cytologii. Obecnie uważa się, że najważniejszym czynnikiem ryzyka rozwoju raka szyjki macicy jest zakażenie wirusem brodawczaka ludzkiego (HPV) komórek nabłonka szyjki macicy.

Ciągły rozwój medycyny niestety nie ma wpływu na istotny spadek liczby zgonów kobiet z powodu chorób nowotworowych. Wydaje się, że istotne znaczenie ma postawa kobiet i ich stosunek do badań profilaktycznych, przy czym zauważyć należy, że profilaktyka nadal nie jest dla nich priorytetem. Świadomość wśród kobiet jest ciągle niska, dlatego należy ją nieustannie zwiększać [13]. 
W przypadku zdiagnozowania u kobiety nowotworu, planowane są działania terapeutyczne, obejmujące jedną metodę leczenia lub leczenie skojarzone, uwzględniające zastosowanie chemioterapii, radioterapii, hormonoterapii, a także operacyjne. W przypadku nowotworów piersi czy narządów rodnych najczęściej wiążą się także z leczeniem chirurgicznym radykalnym lub oszczędzającym [14].

W powrocie do zdrowia i aktywności społecznej bardzo istotną rolę odgrywa psychika pacjentki. Zwłaszcza w przypadku zabiegów operacyjnych piersi ważna jest samoakceptacja kobiety, w tym akceptacja cielesności, eksponowanie kobiecości i przeżywanie intymnej relacji z partnerem (Ja cielesnego) [15].

Tymczasem ponad połowa mężczyzn biorących udział w badaniu „Męskie spojrzenie na kobiety po mastektomii” twierdziła, że akceptuje amputacje piersi, ale kobiety po mastektomii tracą swoją atrakcyjność i nie zaczęliby nowego związku z nimi. Podnosi na duchu fakt, że ponad 90\% ankietowanych deklaruje, że partnerki po zabiegu, jakim jest mastektomia, nie tracą w ich oczach fizycznej atrakcyjności. Są oni chętni do niesienia wsparcia i pomocy swoim partnerkom w czasie rekonwalescencji [16].

W toku badań przeprowadzonych w Klinice Onkologii UJ CM w okresie od marca do grudnia 2015 roku w grupie kobiet w wieku 18-65 lat po mastektomii lub zabiegu oszczędzającym zdiagnozowano: akceptację własnej cielesności, definiowaną przez stopień zadowolenia kobiety z własnego wyglądu i aktualnej sylwetki, sposób doświadczania siebie w intymnej, cielesnej relacji z mężczyzną, akceptację i eksponowanie swojej kobiecości, stosunek do przyjmowania pożywienia i utrzymywania określonej wagi ciała [15]. W wyniku badań stwierdzono, że operacyjne leczenie raka piersi pozostaje $\mathrm{w}$ istotnym związku ze sposobem przeżywania swojego ciała przez badane kobiety. Po mastektomii, jak i po operacjach oszczędzających pierś istnieje podobne ryzyko obniżenia akceptacji własnej cielesności i pogorszenie przeżywania relacji intymnych $\mathrm{z}$ partnerem, przy czym pacjentki bardziej eksponują kobiecość, co może odzwierciedlać mechanizm kompensacji utraconego lub okaleczonego atrybutu kobiecej identyfikacji (piersi) i odbudowy poczucia własnej wartości. Nie zaobserwowano zmian w stosunku do jedzenia i wagi ciała u kobiet po operacji piersi ze wskazań onkologicznych [15].

Badania dotyczące satysfakcji seksualnej kobiet po mastektomii prowadzone były w ramach ogólnopolskiego projektu „Seksualność kobiet po mastektomii”, kierowanego przez prof. Zbigniewa Lwa-Starowicza przy poradniach i w oddziałach onkologicznych na terenie województwa małopolskiego i śląskiego oraz Stowarzyszenia Amazonek w grupie pacjentek w wieku 18-65 lat [17]. W wyniku badań okazało się, że kobiety 18 miesięcy po zabiegu mastektomii radykalnej gorzej oceniały swoją seksualność niż kobiety 5 lat po operacji zabiegu usunięcia piersi (istotny związek z czasem potrzebnym do oswojenia się z nową sytuacją i akceptacją okaleczenia). Tymczasem partnerzy w większości kontaktów seksualnych osiągali przyjemność i satysfakcję. Kobiety 18 miesięcy po zabiegu stwierdziły, że ich współżycie odbywa się rzadziej niż przed wykryciem choroby, natomiast pacjentki 5 lat po mastektomii określały częstotliwość współżycia jako wystarczającą. Jakość życia znacznie osłabia odczuwanie lęku i zaburzenia nastroju bez względu na czas, jaki upłynął od mastektomii [17].

W latach 2005-2008 w Poradni Onkologicznej Szpitala im. S. Leszczyńskiego oraz w Śląskiej Lidze Walki z Rakiem w Katowicach przeprowadzono badania dotyczące seksualnego funkcjonowania w małżeństwie i własnego obrazu kobiet po leczeniu raka macicy dokonane z perspektywy pacjentek i ich zdrowych mężów. W badaniach wzięły udział pary małżeńskie, w których żony zakończyły podstawowe leczenie raka macicy co najmniej pół roku przed konsultacją psychologiczną [18].

W wyniku badań stwierdzono, że: istnieją duże rozbieżności między oceną małżeńskiego funkcjonowania seksualnego, samooceną i obrazem kobiety z perspektywy kobiet leczących się z powodu raka macicy oraz ich mężów. Wskazuje to na obszary zagrożeń w małżeńskim funkcjonowaniu, których przyczyny tkwią w braku dobrej, otwartej komunikacji między partnerami. Efektem zaburzeń komunikacji a jest niepełna małżeńska wiedza o zmianach w uczuciach, myślach, zachowaniach żon, wywołanych leczeniem raka macicy. Kobiety po histerektomii mają znacznie obniżoną samoocenę oraz trudności emocjonalne, poznawcze i behawioralne w małżeńskim funkcjonowaniu seksualnym. W związku z tym unikają dotyku, negliżu, traktują seks jako obowiązek. Kompensują niepełną wg swego mniemania rolę żony dobrym funkcjonowaniem w pozostałych rolach społecznych (matki, pracownika). Ich partnerzy nie dostrzegają problemów w życiu seksualnym [18].

Mimo świadomości stanu zdrowia partnerki, chęci towarzyszenia jej w chorobie, część stałych związków rozpada się po zakończeniu terapii. Jako przykład można podać Kylie Minogue, która tuż po wygranej batalii $\mathrm{z}$ rakiem piersi rozstała się z partnerem, o którym mówiono, że towarzyszył jej w chorobie. Wg badań Macmillan Cancer Support co siódmy związek rozpada się w wyniku choroby nowotworowej jednego z partnerów [19].Wg badań przeprowadzonych na Uniwersytecie Stanu Waszyngton, Uniwersytecie Stanforda i Uniwersytecie Stanu Utah mężczyźni średnio siedem razy częściej porzucają partnerki, u których wykryto raka lub stwardnienie rozsiane, niż kobiety swoich partnerów z podobną diagnozą. Odsetek separacji lub rozwodów wynosił prawie $21 \%$ w przypadku przewlekłej choroby kobiety, zaś 3\% w przypadku zachorował mężczyzna [20]. Z psychologicznego punktu widzenia przyczynami takich rozstań może być: chęć wzajemnej ochrony, a przez to ukrywanie swoich uczuć, co prowadzi do powstania dystansu $\mathrm{w}$ relacji. Także zmiana ról, przesunięcie środka odpowiedzialności za sprawy bytowe, a przez to odczucie ciężaru przez osobę zdrową, może dawać poczucie, że zawiodła partnera. Często od osób, które odchodzą od chorego partnera usłyszeć można stwierdzenia: „To mnie przerasta” [19], a od ich partnerek: „Byłam chora, ale to on się „załamał"” [20]. Niektórzy mężczyźni odchodzą wkrótce po rozpoznaniu nowotworu u partnerki, część wspiera je początkowo, ale kiedy kobieta czuje się nieatrakcyjna 
i unika intymnych relacji, mężczyzna oddala się, zamyka się sobie i znajduje pocieszenie w romansie, nie opuszczając partnerki, ale równocześnie czekając na propozycję rozstania, która padnie z jej ust. Sprowadza się do stwierdzenia: „Nie mógł poradzić sobie z moją chorobą, nasz związek nie był zbyt silny i pewnie i tak by się rozpad’” [19]. Bywa i tak, że jest to romans ze wspólną znajomą, co dodatkowo pogłębia smutek chorej kobiety i pogarsza jej samoocenę [20]. Według pracującej z pacjentami Fundacji Rak Off w Poznaniu psycholog i psychoterapeutki Sabiny Sadeckiej równie częste są jednak rozstania psychologiczne, które wyglądają w ten sposób, że partnerzy stwarzają pozory bycia razem przy równoczesnej dramatycznej samotności każdego z nich. Także psychoonkolog współpracująca z Federacją Stowarzyszeń Amazonki Katarzyna Cieślak podkreśla, że rak jest próbą dla małżeństwa, często uwypuklającą to, co w nim nie funkcjonowało. Często też kryzys wiąże się ze zmianą w wyglądzie partnerki, czy też brakiem intymnych relacji [20].

Inaczej układają się relacje kobieta - mężczyzna wtedy, gdy partnerzy poznają się w trakcie, albo po leczeniu. Zwłaszcza, gdy poprzedni związek kobiety się rozpadł na skutek choroby nowotworowej. Kolejny partner, świadomy możliwości nawrotów choroby, zwykle wspiera partnerkę, ale też oboje umiejętnie korzystają $z$ oferowanej pomocy np.: przez poradnię rodzinną. Wówczas związek ma szansę rozwijania się i staje się trwały i silny. Odejście partnera może prowadzić do prób samobójczych, stąd ważne jest wzajemne wsparcie kobiet w różnego rodzaju organizacjach oraz stały dostęp do specjalistów z zakresu psychologii, gdyż osoby zmagające się z nowotworami nie powinny być samotne. Najważniejsze jest jednak to, aby kobieta miała odwagę przyznać się przed samą sobą, że potrzebuje pomocy [19].

W Wielkiej Brytanii lekarze wzrost badań genetycznych określili mianem „efektu Angeliny Jolie”. Znalazło to potwierdzenie w statystykach brytyjskiego NHS, gdyż odnotowano dwukrotny wzrost badań na obecność mutacji genów BRCA1 i BRCA2, odpowiedzialnych za nowotwór piersi i jajników [21]. I nawet jeżeli podane źródło nie jest zbyt wiarygodne, to niewątpliwie skłania większość swoich czytelniczek do podjęcia działań profilaktycznych. Obecnie, w epoce mediów, bardzo ważne jest wsparcie akcji profilaktycznych przez świadectwa celebrytek, które wygrały walkę z rakiem i otwarcie się do tego przyznają, jak Kylie Minogue, Anastacia, Sheryl Crow, Cynthia Nixon, Christina Applegate, Jaclyn Smith, które aktywnie włączają się w akcje promujące badania profilaktyczne. Nowotwór piersi nie ominął także tej, której piersi zawsze były podziwiane, czyli Brigitte Bardot. Z polskich gwiazd walkę z rakiem efektywnie podjęły: Irena Santor, Beata Kawka, Krystyna Kofta, Marzena Sienkiewicz, Anna Seniuk czy Ewa Minge (współpracuje aktywnie z Amazonkami). Wszystkie panie angażują się w propagowanie badań profilaktycznych. Zauważyć należy, ze znane piękności poddały się mastektomii lub histerektomii w celu uniknięcia choroby, gdyż znajdują się w grupie wysokiego ryzyka. Można wymienić tu chociażby Angelinę Jolie czy Christina Applegate.

\section{WNIOSKI}

1. Niedostateczna liczba lekarzy specjalistów w zakresie onkologii powoduje, że nie każda pacjentka ma szansę na wcześniejsze zdiagnozowanie i rozpoczęcie leczenia. W konsekwencji prowadzi to do dużej umieralności wśród kobiet, która w Polsce nie wykazuje tendencji spadkowej.

2. Regularne badania, tj. cytologia i samobadanie piersi mogą przyczynić się do spadku liczby zgonów z powodu dwóch najgroźniejszych nowotworów kobiecych.

3. Rozpoznanie nowotworu raka piersi, szyjki macicy oraz jego skutki mają negatywny wpływ na psychikę kobiet, a zwłaszcza postrzeganie swojej kobiecości. W związkach, w których istniała silna więź uczuciowa przed chorobą kobiety, zauważono poprawę życia seksualnego. Ważnymi czynnikami wpływającymi na tę relację są: samoakceptacja kobiety i poczucie atrakcyjności.

4. Duże nakłady finansowe na programy profilaktyczne nie gwarantują zwiększenia wykrywalności nowotworów i spadku liczby zgonów.

\section{PODSUMOWANIE}

Nowotwory są bardzo częstym powodem zgonów w Polsce i na świecie. Nowotwory najczęściej występujące u kobiet to: rak piersi, rak płuc, rak trzonu macicy i rak jelita grubego. Istnieje wiele czynników, zwiększających ryzyko wystąpienia nowotworu np. wiek, czynniki genetyczne czy alkohol i papierosy. W celu zwiększenia szansy na skuteczne leczenie nowotworu, powinien być on wcześnie wykryty. Dlatego też kobiety powinny regularnie wykonywać badania profilaktyczne, takie, jak np.: samobadanie piersi, USG piersi, mammografię, cytologię oraz inne, zgodnie $\mathrm{z}$ kalendarzem badań zalecanych dla kobiet. Niestety mimo wielu programów profilaktycznych odsetek zachorowań na nowotwory wśród kobiet wciąż rośnie. Również umieralność bardzo rzadko wykazuje stałą tendencje spadkową, dlatego bardzo istotnym elementem jest profilaktyka, badania, zdrowy tryb życia i nieustające akcje edukacyjne i medialne.

\section{ORCID}

Małgorzata Pabiś (iD) https://orcid.org/0000-0001-7260-8996 Kinga Augustowska-Kruszyńska (iD https://orcid.org/0000-0001-8130-2788

\section{REFERENCES/PIŚMIENNICTWO}

1. Krajowy Rejestr Nowotworów: http://onkologia.org.pl/nowotwory-wprowadzenie/ [dostęp 10.07.2019].

2. Krajowy Rejestr Nowotworów: http://onkologia.org.pl/raporty/\#wykres_kolowy [dostęp 10.07.2019]

3. Didkowska J, Wojciechowska U, Olasek P, Czauderna K. Nowotwory złośliwe w Polsce w 2014 roku. Warszawa: Centrum Onkologii - Instytut; 2014.

4. Didkowska J, Wojciechowska U, Olasek P. Nowotwory złośliwe w Polsce w 2015 roku. Warszawa: Centrum Onkologii- Instytut; 2015.

5. Krajowy Rejestr Nowotworów: http://onkologia.org.pl/k/0-nowotworach/ [dostęp 10.07.2019].

6. World Health Rankings Live Longer Live Better: https://www.worldlifeexpectancy. com/world-health-rankings?fbclid=IwAR2L_A5hAk08qmyWGRlukQxvAVHjS6GEV vHMsi-w-I0canSOcbW5E5bDvm0 [dostęp 7.07.2019]. 
Małgorzata Pabiś, Kinga Augustowska-Kruszyńska, Weronika Kozicka, Kamila Kułaczkowska, Diana Kuzioła

7. Krajowy Rejestr Nowotworów: http://onkologia.org.pl/nowotwory-zlosliweogolem-2/ [dostęp 10.07.2019].

8. Narodowy Fundusz Zdrowia: http://nfz.gov.pl/dla-pacjenta/programy-profilaktyczne [dostęp 10.07.2019].

9. Ławniczak A. Badania profilaktyczne kobiet. Kalendarz badań profilaktycznych: https://www.poradnikzdrowie.pl/sprawdz-sie/badania/badania-profilaktycznekobiet-kalendarz-badan-profilaktycznych-aa-AY4L-XtuR-DXQS.html [dostęp 10.07. 2019].

10. Główny Urząd Statystyczny. Bank Danych Lokalnych: https://bdl.stat.gov.pl/BDL/ start [dostęp 10.07.2019].

11. Naczelna Izba Lekarska: https://nil.org.pl/rejestry/centralny-rejestr-lekarzy/informacjestatystyczne [dostęp 10.07.2019].

12. Krajowy Rejestr Nowotworów: http://onkologia.org.pl/rak-piersi-kobiet/ [dostęp 10.07.2019].

13. Krajowy Rejestr Nowotworów: http://onkologia.org.pl/nowotwory-szyjki-macicy/ [dostęp 10.07.2019].

14. Chirurgia onkologiczna - chirurgiczne leczenie raka i nowotworów: http://www. onkonet.pl/dp_chirurgia_onkologiczna.php [dostęp 10.07.2019].

15. Jabłoński MJ,Streb J, Mirucka B, i wsp.ZZwiązek leczenia chirurgicznego (mastektomia vs. zabieg oszczędzający pierś) z akceptacją cielesności, eksponowaniem kobiecości i przeżywaniem intymnej relacji z partnerem $w$ grupie kobiet $z$ rakiem piersi. Psychiatria Polska, 2018; 52(5): 859-872.

16. Samek K. Agnieszka Badura: Wciąż kobiece Amazonki: http://www.eksmagazyn. $\mathrm{pl} /$ wazny-temat/ekscentryczna-bohaterka/agnieszka-badura-wciaz-kobieceamazonki [dostęp 7.07.2019].

17. Białek K, Bolek K, Kowalczyk R, Lew-Starowicz Z. Seksualność i jakość życia kobiet badanych do 18 miesięcy i 5 lat po zabiegu mastektomii - analiza porównawcza. Państwo i Społeczeństwo. 2015; 4(15): 121-129.

18. Pietrzyk A. Seksualne funkcjonowanie w małżeństwie i własny obraz kobiet po leczeniu raka macicy. Perspektywa pacjentek i perspektywa ich zdrowych mężów. Seksuologia Polska. 2009; 7(2): 35-45.

19. Haywood L. Masz raka? Odchodzę! https://kobieta.onet.pl/dziecko/masz-rakaodchodze/7vj7m [dostęp: 01.07.2019].

20. Groza A. Mam raka, mąż mnie zostawił: https://kobieta.onet.pl/zdrowie/zycie-izdrowie/zdrada/mam-raka-maz-mnie-zostawil/415xchq [dostęp: 01.07.2019].

21. Hofman-Pyka K, Witkoś A, Lisik T, Nowakowska-Zajdel E. Late recurrence of breast cancer in a patient with BRCA1 mutation and subsequent radical treatment for colorectal and endometrial cancer - a case report. Oncology in Clinical Practice. 2016; 12: 29-32.
Manuscript received/Praca zgłoszona do czasopisma: 02.08.2019

Manuscript accepted/Praca zaakceptowana do druku: 24.03.2020

Translation/Tłumaczenie: Weronika Topolan, UM w Lublinie 